International Journal of Applied Linguistics \& English Literature

ISSN 2200-3592 (Print), ISSN 2200-3452 (Online)

Vol. 1 No. 7; November 2012 [Special Issue on Applied Linguistics]

\title{
Reconciling Diverse Communities through Language Policy Practices in Malaysia
}

\author{
Ain Nadzimah Abdullah \\ Faculty of Modern Languages and Communication \\ Universiti Putra Malaysia \\ 43400 UPM Serdang, Selangor \\ E-mail: ain@fbmk.upm.edu.my \\ Chan SweeHeng \\ Faculty of Modern Languages and Communication \\ Universiti Putra Malaysia \\ 43400 UPM Serdang, Selangor
}

Received: 20-10- 2012

Accepted: 22-11- 2012

Published: 25-11- 2012

doi:10.7575/ijalel.v.1n.7p.51

URL: http://dx.doi.org/10.7575/ijalel.v.1n.7p.51

\begin{abstract}
Malaysia is an example of a diverse nation with communities facing multiplicities in religions, languages, linguistic practices and cultural beliefs. These multiplicities and polarities need to be understood and managed in order to maintain harmony and unity in this multilingual and multicultural nation. Malaysia, therefore, has to strategize and build up paths that would lead to a solid foundation of trust and cohesiveness among its citizens. This paper seeks to achieve a better and clearer understanding of Malaysian language policies and the relationships in linguistic practices that are seen to contribute to the reconciliation among diverse communities. The paper investigates the language phenomenon through a survey questionnaire that would give information about the relative emphases given to the use of the various languages, and perceptions about issues pertaining to language maintenance. Data reveal diversities in language use in relation to ethnicity and the reconciliations that emerge from these diversities. The reconciliation is an adopted move towards a more united and inclusive community creating "oneness" within multi-ethnic, multi-lingual and multi-cultural Malaysia. The results are also linked to the current program for transformation of Malaysian society under the context of a mission for unity.
\end{abstract}

Keywords: Language planning, Language policy, Multilingual

\section{The Linguistic Situation in Malaysia}

Malaysia is a multilingual, multicultural and multiracial country where everyone speaks at least two or more languages. The multilingual situation in Malaysia came about primarily due to trade and other economic and social reasons. Historically, the early European languages that came to Malaysia were Portuguese and Dutch. These languages were followed later by English, with the British colonization beginning in the late 18th century. As a British colony, the use of English occupied formal and informal domains. During this period, Chinese and Indian languages also set foot in Malaysia with the migration of Chinese and Indian labor to Malaysia to serve in the tin mines and rubber plantations. The use of English spread rapidly molding an elite group of local users among the Malays, Chinese and Indians who attended English-medium schools. At the same time it was also noted that English-medium schools in Malaysia was on the rise linked inextricably to the increasing popularity of the English language. At this stage of development, English was clearly identified as having a distinct relative advantage over other languages and its status was confirmed by the emphasis given in the education system. Rewards were clearly economic in terms of job opportunities and career advancement.

\section{English as Medium of Instruction}

The ability to use English proficiently was perceived by most citizens as a necessity which did not clash with 
International Journal of Applied Linguistics \& English Literature

ISSN 2200-3592 (Print), ISSN 2200-3452 (Online)

Vol. 1 No. 7; November 2012 [Special Issue on Applied Linguistics]

existing nationalistic or ethnic values and practices. While it was a language foreign to most of the citizenry, and therefore complex, the education system nonetheless laid complete emphasis on the language in the curriculum by using it as a medium of instruction. Without dispute, it produced a generation of competent users of the English language and this "colonial experiment" went on trial for more than three decades after independence in 1957. However, it should be noted that the British Raj allowed ethnic schools - Indian, Chinese and even Punjabi. The recognition given to languages other than English and the national language, Bahasa Malaysia is regarded as a conciliatory effort of the government to respect and promote linguistic diversity.

\section{Malaya to Malaysia}

In 1957, Malaya (afterward Malaysia) gained independence from the British and with it autonomy to take charge and chart her own destiny. With independence, Malaysia inherited an education system that was considered to be a colonial leftover and had to be changed to reflect the new identity of the newly independent nation. At that point, Bahasa Malaysia and the English language became the main languages for education. However, the primary vernacular languages (Mandarin Chinese and Tamil) survived as medium of instruction in vernacular schools at the primary school level as provided by the Article 152 of the Malaysian Federal Constitution (2002). Article 152 states that the national language is the Malay language.

In relation to other languages, the Constitution provides that: (a) everyone is free to teach, learn or use any other languages, except for official purposes. Official purposes here means any purpose of the Government, whether Federal or State, and includes any purpose of a public authority (b) the Federal and State Governments are free to preserve or sustain the use and study of the language of any other community. Article 152(2) created a transition period for the continued use of English for legislative proceedings and all other official purposes. For the States in Peninsular Malaysia, the period was ten years from Merdeka (Independence) Day and thereafter until Parliament provided otherwise. Parliament subsequently enacted the National Language Acts 1963/67 which provided that the Malay language shall be used for all official purposes. The Acts specifically provide that all court proceedings and parliamentary and state assembly proceedings are to be conducted in Malay, but exceptions may be granted by the judge of the court, or the Speaker or President of the legislative assembly. The National Language Act (1963) saw the demise of the use of English as medium of instruction, officially replaced by the Malay language.

At the secondary level, the Malay language was used as the sole medium of instruction. The concession for the use of the vernacular languages at the primary level was an attempt to appease the ethnic minorities (Indians and Chinese) who essentially felt the need to safeguard their identities through mother tongue preservation. This unique arrangement led to a language situation which is diverse complex and intricate. The new language situation led to diminished importance in the use of English. However, while this was so, its status as a super-ordinate language remained and continued to enjoy a high esteem right to the present times. Asmah (1996) recognizes this situation as a consequence of nationalism and "nationism". The distinction lies in nationalism attending to national aspirations of a united race, and "nationism" playing its role in developing Malaysia as an industrial nation to take its place in internationalism (p. 71).

In 2002, another language planning and policy innovation further impacted language use in education in Malaysia. The milestone change was the reversion to the use of English for the teaching of mathematics and science in schools. Generally, it set the direction towards a greater emphasis on becoming multilingual (using Malay, English and ethnic languages). The policy was an attempt at acquisition planning for the nation's school-going population. The initiative was short-lived though. The policy was reversed in 2009 to the former policy of only using Bahasa Malaysia for the teaching of Mathematics and Science. It was a difficult decision for the government but it was seen as an attempt at preserving and upholding the status and role of the national language. English, however, was promised institutional support and emphasis in education as long as the national language was not debased. The language policy introduced subsequently was known as MBMMBI (Mertabatkan Bahasa Melayu, Memperkukuhkan Bahasa Inggeris), translated in English to mean to uphold Bahasa Malaysia \& to strengthen the English language. This policy is aimed to ensure the usage of Malay Language as a medium of communication in all national schools and secondary schools, and to ensure that each child can master both Malay and English languages well and fluently. To uphold Bahasa Malaysia means to place the language in its rightful position as the national language as enshrined in Article 152 of the Federal Constitution. To strengthen the English language means to enhance the command of the language as a 
International Journal of Applied Linguistics \& English Literature

ISSN 2200-3592 (Print), ISSN 2200-3452 (Online)

Vol. 1 No. 7; November 2012 [Special Issue on Applied Linguistics]

compulsory language to be learned, the language of communication and of knowledge at the national and international levels (http://www.scribd.com/doc/84464558/MBMMBI).

Recently, in September 2012, in yet another educational initiative, the Malaysian Education Blueprint (2013-2025) was unveiled by the Prime Minister. The blueprint focuses on producing six key "attributes" for students, among which is bilingual proficiency. The master plan also revealed statements about Bahasa Malaysia being the cornerstone of Malaysia's language policy with the English language given the necessary exposure to increase the ability in the language. It is envisioned that the Malaysian Education Blueprint is going to have tremendous impact on the learning of languages and for the fulfilling of national aspirations. According to Ibrahim Bajunid, a prominent Malaysian educationist, the blueprint is the roadmap to transform Malaysian education and to ensure that the nation has one of the best systems of education in the world. He also said that in the interest of the future, the Education Blueprint hopes to foster the coalition of the willing across the political divide (Bajunid@www.nst.com.my).

As a nation with communities diverse in religions, languages and cultural beliefs, it is important to understand and manage these multiplicities in order to maintain harmony. Malaysia therefore has to strategize and build up paths that would lead to a solid foundation of trust and cohesiveness among its citizens. This paper will discuss language policy, linguistic practices and language beliefs in Malaysia to illuminate language efforts aimed at reconciliation among very diverse communities.

\section{Aspects of Language Policy}

In Malaysia, language policy decisions have often been embroiled in one controversy or another, fuelled by contrived notions of nationalism, political philosophy, and ideals of what it means to be a Malaysian. In order to understand any kind of language policy, there is a need to look and understand it in a broader framework. Politics of language have always been very important when questions about ethnicity or self-identification are involved. Harold Schifmann (2005) calls this linguistic culture, that is, the set of behaviors, assumptions, cultural forms, prejudices, folk belief systems, attitudes, stereotypes, ways of thinking about language, and religio-historical circumstances associated with particular language(s). Schiffman considers it to be futile to regard only the overt language policies, or the policies that are in other words explicit, formalized, codified or manifested. He suggests looking also the covert language policies: the policies, which are not necessarily officially stated, but still carried through in a society, in other words implicit, informal, unstated, de facto, grass-root or latent. Schiffman also differentiated between three main types of language policies: centralized policies such as a la French language policy, laissez-faire policy like in the USA, and the multilingual policy, as implemented, for example, in Switzerland and India. These classifications are broad-based but reasoned. He emphasizes the importance of investigating the linguistic culture in which the policies are being implemented, in order to understand its goals and reasons for implementation. It is with these thoughts that this study was based.

\section{Methodology}

Data were collected through an anonymous written questionnaire administered to a random sample of 60 undergraduate students at Universiti Putra Malaysia. The undergraduate students were from various different academic programs at Universiti Putra Malaysia and they were in the final year of their study. Respondents (40 male, 20 female) were asked to report on their own beliefs and ideas about language policy decisions in Malaysia, with particular reference to the national language and English language use. The purpose of the questionnaire was explained to the respondents, and then the respondents were left alone to complete the questionnaire in the presence of the researchers, The researchers felt that this method assured a high response rate, allowing for minimum of bias, The researchers were able to provide necessary explanations giving the benefit of personal contact during the data collection stage. The basis of the questions rests on the notion that language beliefs tend to be affected by the functions that a language may fulfill within a given speech community. In addition, language use is often characterized by its potentiality for expression in a range of linguistic domains, i.e. the perceived practical and social worth of the language.

Among the questions asked to the respondents were:

1. Does Malaysia promote the national language?

2. Should the government provide assistance to preserve the national language?

3. Is it better for a country if different racial and ethnic groups maintain their distinct language(s)?

4. Is it better if citizens adapt and blend into the larger society using the national language? 
International Journal of Applied Linguistics \& English Literature

ISSN 2200-3592 (Print), ISSN 2200-3452 (Online)

Vol. 1 No. 7; November 2012 [Special Issue on Applied Linguistics]

5. Does Malaysia promote the English language?

6. Does English enjoy great prestige in the country as a language of power?

7. Is competence in English a key to advancement in Malaysian society?

8. Is English a requirement for gaining employment in Malaysia?

9. Does the English language play a role in promoting unity among Malaysian?

10. Are both (Bahasa Malaysia an English) languages equally promoted in Malaysia?

11. Can Bahasa Malaysia and English together promote racial harmony?

12. Would Malaysian language policy result in a Malaysian who is equally proficient in both Bahasa Malaysia and English?

13. Does the Malaysian language policy help to develop the global Malaysian?

\section{Responses to the questions}

Most of the respondents $(90 \%)$ articulated that a common language helps to unite the country and that the national language is the main identity of a nation. In addition, they indicated that it can assist in the creation of literature and a literary and cultural history for the nation. 58 of the 60 respondents also vehemently agreed that language is the vehicle of culture and marker for identity. However, the English language is seen as opening pathways not only to careers but also to fulfillment in identifying with the global and economic community at large. Responses were positive towards the use and learning of the English language. Given the importance of communication in fostering links between people, it is not surprising that the English language continues to have a high prestige in the country and respondents confirmed that competence in English was a key for advancement in society. They acknowledged that English is the language most often needed in order to get a worthwhile job and the ability to use the language well was important for employment and career development. While recognizing its utilitarian value, the respondents also expressed that the invasion of English language has eroded somewhat the fabric of Malaysian culture and traditions. According to Subramaniam (2007), “....in the context of Malaysia, changes to the institutional role and status of the English language has waxed and waned to a point of near extinction only to re-emerge stronger in the 21 st century."

\section{What are some current concerns of the Government and the public?}

The Prime Minister has often reiterated that the goal of creating a society that can capture at least two languages is the focus of which will be applied in all Malaysian language and educational policies. The Prime Minister said, the national language is one that must be mastered by the students and they should be able to speak and write the language well. He further added: "The national language is our identity that we must continue to fight for and I also want students to be proficient in English. If possible we also want to produce a trilingual society. This is because the various languages will increase our competitiveness in the globalized world." The Prime Minister also said that, "....another important aspect that we are looking at is the need to produce human capital who can master more than one language or who are multilingual. Advancements in the information, communication and transportation technologies have made this an important imperative as the whole world is now one big potential marketplace for our goods and services, we must take advantage of this situation" (Najib Razak, 16 June 2009).

The language issue that continues to receive attention is the 2009 reversal of the use of the English language in the teaching of science and mathematics. As recent as August 2011, the government declared an open mind to a dual language system for implementation in spite of the official announcement of the reversal. The government and the public continue to express their views about the need to improve the standard of the English language. Some associations remain steadfast in urging the government for a rethink about the 2009 reversal. There is an entrenched belief that a choice should be given to students and parents to have a say in determining the path of education and by default the policy made. Amidst the developments, it was concluded that "there is a serious rift in the public discourse of education and language..." and at the end of the experiments, "it is the students who become the victims" (The Star, 14 August 2011).

\section{Conclusion}

Language ideology and the practicing language policy should capture and guide the principled language practices that lead to good governance in a community. The harmony of Malaysia rests fundamentally on the peaceful co-existence of three major ethnic communities: Malay, Chinese and Indian. These communities are 
International Journal of Applied Linguistics \& English Literature

ISSN 2200-3592 (Print), ISSN 2200-3452 (Online)

Vol. 1 No. 7; November 2012 [Special Issue on Applied Linguistics]

characterized by the use of ethnically distinct languages: Bahasa Malaysia, Chinese and Indian languages. In addition, there is the undeniable pervasive use of the English language across these communities.

The 21st century Malaysian must be one who is accepting, tolerant and open-minded. But all these require sacrifices. It may mean letting go of some current bias and prejudice, mentally and emotionally. It is a scary thing to do, letting go, because this means that we are going out of our comfort zone, to some place that is unknown. We think that that by letting go, we are sacrificing our values, our beliefs, our language, our culture, our identity. As a result, the language policy of Malaysia remains subject to much discussion and debate. However, to move forward, Malaysia needs to see the woods from the trees, and resolve some thorny issues about the language policy so that it offers and charts out more definite paths for the benefit of the society.

\section{References}

Asmah Haji, O. (1996). Language Planning and Image Building: The Case of Malay in Malaysia. International Journal of the Sociology of Language: Linguistic Issues of Southeast Asia. 130. p.49-66.

Malaysian Education Blueprint 2013 - 2025. Retrieved from

http://www.moe.gov.my//Preliminary-Malaysia-Education-Blueprint-2013-2025-English

Malaysian Federal Constitution (2002). Retrieved from

http://confinder.richmond.edu/admin/docs/malaysia.pdf

MBMMBI. Source: http://www.scribd.com/doc/84464558/MBMMBI

Najib Razak. (2009) Opening Speech 17th Conference Of Commonwealth Education Ministers (17ccem)

Education in the Commonwealth : Towards and Beyond Global Goals and Targets

New Straits Times ( October, , 2010. Retrieved from

http://www.allvoices.com/contributed-news/7045537-malaysian-must-capture-at-least-two-languages-malay-dan -english

On the Malaysian Education Blueprint 2013-2025. Retrieved from Bajunid@www.nst.com.my September 14, 2012

Schifmann, H. (2005). Language Policy and Linguistic Culture. In T. Ricento (ed.) An Introduction to Language Policy: Theory and Method. London: Blackwell 2005.

Retrieved from http://www.pmo.gov.my/?menu=speech\&page=1676\&news_id=132\&speech_cat=2

Subramaniam, G. (2007). The Changing Tenor of English in Multicultural Postcolonial Malaysia. $3 L$ The Southeast Asian Journal of English Language Studies, 13, . 1-23.

The Star, 14 August 2011. Retrieved from http://thestar.com.my/education/story.asp?file=/2011/8/14/education/9293221\&sec=education 